\title{
IMPLEMENTASI METODE EUCLIDEAN DISTANCE UNTUK REKOMENDASI UKURAN PAKAIAN PADA APLIKASI RUANG GANTI VIRTUAL
}

\author{
Rezky Rizaldi' ${ }^{1}$, Arik Kurniawati ${ }^{2}$, Cucun Very Angkoso ${ }^{3}$ \\ 1,2,3 Teknik Informatika, Universitas Trunojoyo Madura \\ Email: ${ }^{1}$ rezky13023@gmail.com, ${ }^{2}$ arik@if.trunojoyo.ac.id, ${ }^{3}$ cucunvery@if.trunojoyo.ac.id
}

(Naskah masuk: 10 Januari 2018, diterima untuk diterbitkan: 16 April 2018)

\begin{abstract}
Abstrak
Perkembangan jual beli garmen secara online, dihadapkan pada kenyataan adanya $70 \%$ pengembalian produk oleh pembeli, akibat ketidaksesuaian antara harapan dan kenyataan model serta ukuran garmen. Kehadiran virtual fitting room secara online, diharapkan mampu mengurangi adanya pengembalian produk, memberikan pengaruh positif terhadap keistimewaan suatu produk, keinginan untuk membeli dan kepastian membeli secara online. Virtual Fitting Room ini bisa diimplementasikan pada toko online ataupun toko baju seperti biasa. Tahapan penelitian meliputi : penerapan teknologi kinect untuk mendapatkan data skeleton dari calon pembeli yang digunakan sebagai dasar untuk memberikan rekomendasi ukuran pakaian, selanjutnya perhitungan euclidean distance digunakan untuk menghitung ukuran punggung calon pembeli dan terakhir penerapan teknologi augmented reality untuk menampilkan pakaian virtual 3 dimensi yang melekat tepat di badan calon pembeli. Sistem rekomendasi ini mampu menampilkan calon pembeli dengan menggunakan baju virtual 3 dimensi yang sesuai dengan ukuran rekomendasi dari sistem (S,M,L, atau XL). Sistem ini juga memberikan fitur bagi calon pembeli untuk mencoba model pakaian lainnya. Sistem dapat memperlihatkan baju virtual 3 dimensi yang tetap melekat pada badan calon pembeli, ketika melakukan rotasi ke kanan $90^{\circ}$, ke kiri $90^{\circ}$, balik kanan $180^{\circ}$ dan balik kiri $180^{\circ}$. Hasil uji coba sistem rekomendasi ukuran pakaian ini akan berjalan secara optimal jika pengaturan ketinggian kinect sebesar $55 \mathrm{~cm}$ dari tanah. Untuk ketinggian kinect $55 \mathrm{~cm}, 65 \mathrm{~cm}$ dan $75 \mathrm{~cm}$ dari tanah, sistem ini mampu menyajikan kesesuaian rekomendasi ukuran dibandingkan dengan ukuran asli dari calon pembeli sebesar $70 \%$
\end{abstract}

Kata kunci: kinect, augmented reality, euclidean distance, virtual fitting room

\section{RECOMENDER SYSTEM OF APPAREL SIZE IN VIRTUAL FITTING ROOM BASED ON EUCLIDEAN METRIC}

\begin{abstract}
The development of online garment sale, faced with the fact that there is $70 \%$ return of product by the buyer, due to a mismatch between expectation and reality of model and garment size. The presence of virtual fitting room in the online store is expected to reduce the return of products, give a positive influence on the privilege of a product, the desire to buy and certainty to buy online. Virtual Fitting Room can be implemented in the online store or clothing store as usual. The research stages include the application of Kinect technology to obtain skeleton data from prospective buyers used as a basis for providing system recommendations, then euclidean distance calculation is used to calculate the size back potential buyers, and lastly application of augmented reality technology to display the right three-dimensional virtual clothing in potential buyer body. This recommendation system can present potential buyers by using 3-dimensional virtual shirts attached to their bodies by the recommended size of the system $(S, M, L$, or $X L)$. This system also provides features for potential buyers to try other clothing models. The system can show a 3-dimensional virtual shirt that remains attached to the body of potential buyers, while rotating right $90^{\circ}$, left $90^{\circ}$, right turn $180^{\circ}$ and left turn $180^{\circ}$. The test results of this clothing size recommendation system will run optimally if the Kinect height setting of $55 \mathrm{~cm}$ from the ground. For the Kinect height of $55 \mathrm{~cm}, 65 \mathrm{~cm}$ and $75 \mathrm{~cm}$ from the ground, the system can present the recommended size with the original size of the potential buyer of $70 \%$.
\end{abstract}

Keywords: kinect, augmented reality, euclidean distance, virtual fitting room 


\section{PENDAHULUAN}

Fitting Room atau dikenal dengan istilah ruang ganti, ruangan ini biasanya disediakan oleh toko yang menjual produk garmen. Ruang ganti sendiri sebenarnya digunakan oleh calon pembeli untuk mencoba pakaian yang sudah dipilih agar sesuai dengan dirinya (pas/cocok) dalam hal ukuran dan model. Ruang ganti yang nyaman juga merupakan hal yang penting untuk diperhatikan oleh suatu toko. Kenyamanan ini didukung dengan ukuran ruangan, kaca, pencahayaan dan desain ruangan karena faktorfaktor tersebut akan sangat mempengaruhi calon pembeli dalam berbelanja pada suatu toko (Hengevelt, 2014).

Trend saat ini dengan penggunaan internet yang signifikan sangat mempengaruhi potensial bisnis penjualan garmen pada pasar online(Riaz \& Raman, 2015). Berdasarkan survei pada online shopping di pasar Taiwan menunjukan bahwa produk garmen (baju) adalah produk utama yang paling banyak diminati (Liaw \& Chen, 2013). Oleh karena itu diperlukan berbagai cara dalam meningkatkan pelayanan calon pembeli, salah satunya adalah virtual fitting room (Liaw \& Chen, 2013)(Beck, 2015).

Kelemahan utama dari online shopping adalah calon pembeli tidak dapat bereksperimen dan mencoba produk (Beck, 2015). Dalam online shopping, pengembalian produk terutama produk garmen adalah sekitar $70 \%$ dan hanya skitar $30 \%$ yang tidak dikembalikan (Misra \& Arivazhagan, 2015). Hal ini dikarenakan produk tersebut tidak sesuai/tidak cocok dengan harapan calon pembeli. Hal yang berbeda, ketika calon pembeli belanja secara offline, maka dia dapat mencoba dan memegang produk tersebut. Namun dalam belanja online, hal ini menjadi sulit untuk diimplementasikan seperti mencoba ukuran, display produk ke calon pembeli, menunjukan semua bagian dari produk ke calon pembeli, memegang serta mencoba produk garmen tersebut. Harapannya dengan virtual fitting room, sebagian permasalahan tersebut bisa teratasi seperti ukuran yang pas untuk calon pembeli dengan mencobanya secara virtual (Misra \& Arivazhagan, 2015).

Beberapa keuntungan ketika virtual fitting room ini diimplementasikan pada belanja online yaitu (1) calon pembeli mendapatkan keuntungan dan kesenangan ketika memilih dan membeli produk garmen, (2) calon pembeli tanpa ragu-ragu mencoba produknya dengan memanfaatkan teknologi ini, sehingga bisa berlanjut menjadi membeli, (3) merk dari produk garmen tersebut juga akan dikenal (Liaw \& Chen 2013).

Salah satu survey dalam belanja online, penggunaan virtual fitting room dapat memberikan pengaruh postif terhadap persepsi keistimewaan suatu produk, keinginan untuk membeli (patronage intention) dan kepastian membeli secara online (purchase intention) (Beck, 2015).
Oleh karena itu, penelitian ini mengimplementasikan ruang ganti virtual yang dibangun dengan processing, Simple Open Ni SDK, dan Kinect Microsoft SDK dan menggunakan teknologi Augmented Reality yang dilengkapi dengan rekomendasi ukuran pakaian bagi calon pembeli yang telah mencoba ruang ganti virtual ini.

Rancang Bangun Aplikasi Ruang Ganti Virtual Berdasarkan Skeleton Tracking dan Depth Data Menggunakan Microsoft Kinect. Penelitian ini menghasilkan aplikasi virtual dressing room yang mampu merekomendasikan ukuran pakaian kepada calon pembeli menggunakan metode euclidean distance. Uji coba dilakukan pada 5 calon pembeli dengan jarak antar calon pembeli dengan Kinect kurang lebih 1,6 m. Hasil akurasi yang dihasilkan dari penelitian ini dalam merekomendasikan ukuran pakaian calon pembeli mencapai $80 \%$. Selain itu aplikasi mampu memvisualisasikan augmented reality pakaian 3D ke badan calon pembeli. Namun dalam penelitian ini, kontrol antar muka aplikasi masih sulit untuk mendeteksi pointer berupa tangan dan masih kurang responsif (Negoro, 2015).

Penelitian kedua berjudul Sistem Pengepasan Baju Berbasis Pustaka XNA Menggunakan Kamera Kinect. Penelitian tersebut menghasilkan aplikasi virtual fitting room. Metode yang digunakan untuk penambahan augmented reality berupa pakaian 3D menggunakan library XNA. Dengan memanfaatkan lebar punggung sebagai acuan transformasi dari obyek baju virtual. Hasil dari uji coba pada penelitian ini adalah jarak optimal untuk mendeteksi keberadaan antara pengguna dengan Kinect berkisar antara 1,5 3 meter. Tingkat akurasi aplikasi dalam menghitung rotasi yang dilakukan pengguna mencapai 97,4\% . Namun penelitian ini tidak memfasilitasi adanya sistem yang merekomendasikan ukuran pakaian kepada calon pembeli (Sigit dkk, 2014).

Penelitian ketiga berjudul Analisis dan Design Body Measurment pada Virtual Dressing Room. Penelitian tersebut menghasilkan aplikasi virtual dressing room. Aplikasi tersebut mampu merekomendasikan ukuran pakaian pada pengguna dengan menggunakan 3 metode berbeda yaitu euclidean distance, point cloud euclidean distance, point cloud perimeter ellipse. Hasil dari uji coba yang dilakukan kepada 6 calon pembeli menunjukkan metode euclidean distance memiliki tingkat akurasi yang lebih bagus dari pada metode lainnya. Aplikasi yang dibuat dalam penelitian ini hanya mampu merekomendasikan ukuran pakaian untuk calon pembeli tanpa adanya penambahan augmented reality berupa pakaian 3D (Dewi, 2013). 


\section{METODE}

Teknologi Kinect pada sistem ini digunakan untuk mendapatkan data skeleton dari calon pembeli yang digunakan sebagai dasar untuk memberikan rekomendasi ukuran pakaian. Sedangkan teknologi Augmented Reality digunakan untuk menampilkan pakaian virtual tepat di badan calon pembeli.

Sistem rekomendasi ukuran pakaian yang diimplementasikan dalam penelitian ini menggunakan metode Euclidean Distance. dengan mengaju pada Persamaan (1).

Hasil akhir dari aplikasi ini adalah sistem yang menampilkan calon pembeli dengan menggunakan baju virtual yang melekat pada badannya sesuai dengan rekomendasi ukuran dari sistem (S,M,L,XL). Selain itu, sistem juga memfasilitasi calon pembeli untuk mencoba model lainnya seperti yang diilustrasikan pada Gambar 1 berikut ini.

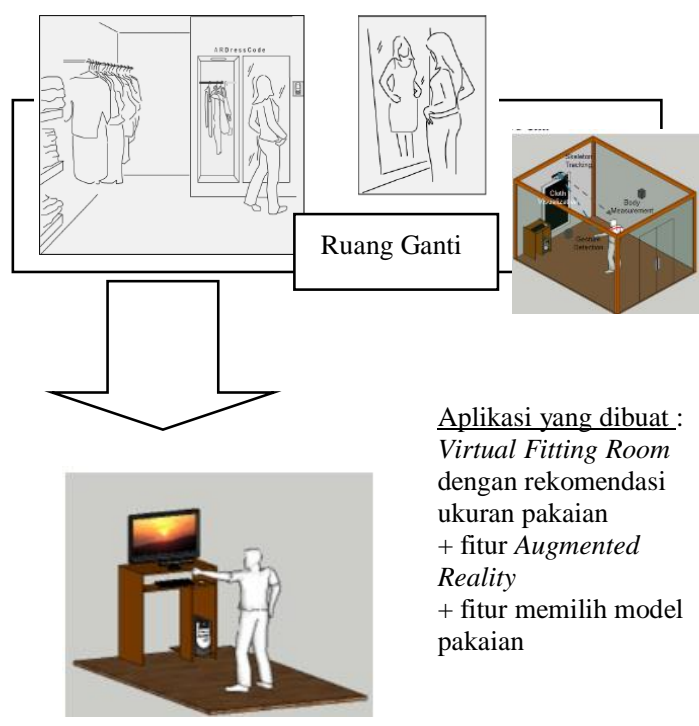

Gambar 1. Ilustrasi sistem ruang ganti virtual

Secara umum proses kalibrasi ditangani oleh Kinect, dimana Kinect mempunyai fitur $3 D$ Object Tracking. Fitur tersebut dapat mengenali semua bentuk benda yang ada disekitarnya dengan memanfaatkan 3D Depth Sensor dan RGB Camera. 3D Depth Sensor atau sensor kedalaman yakni berupa sebuah proyektor infrared dan sebuah sensor monochrome CMOS yang bekerja sama untuk mengenali ruangan dalam bentuk 3 Dimensi. Sedangkan $R G B$ Camera adalah camera video yang membantu dalam mendeteksi 3 komponen warna yaitu Merah, Hijau dan Biru. Sensor-sensor inilah yang membuat Kinect dapat mengenali badan pengguna seperti yang diilustrasikan pada Gambar 3 .

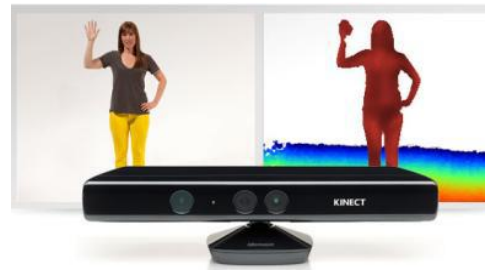

Gambar 3. 3D Object Tracking pada Kinect (Hruska , 2016)

Skeletal Tracking adalah mendapatkan data skeleton dari pengguna yang berada dalam jangkauan jarak pandang Kinect. Data skeleton yang didapat adalah seperti yang ditampilkan dalam Gambar 4.

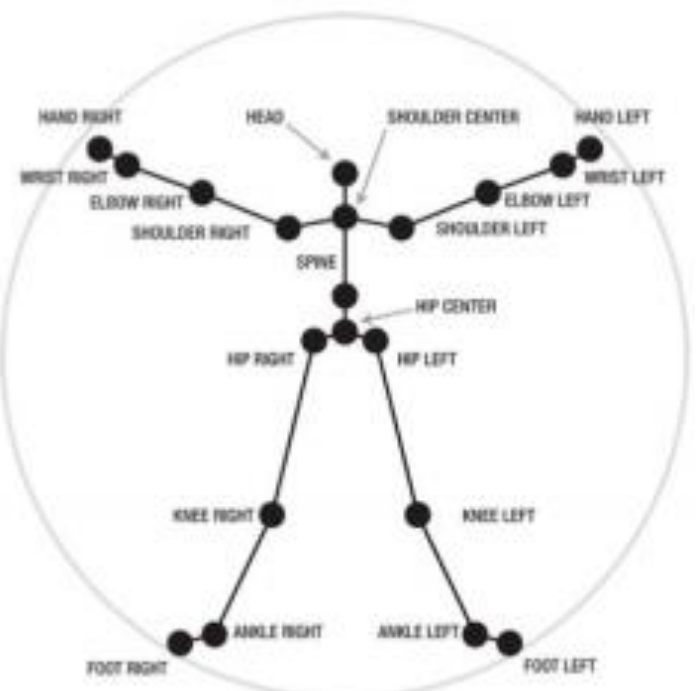

Gambar 4. Data skeleton dari Kinect (Webb dkk, 2012)

Augmented Reality adalah cara untuk menggabungkan dunia riil dengan dunia virtual (Azuma, 1997) yang dibuat melalui komputer sehingga batas antara keduanya sangat tipis. Tipe Augmented Reality (AR) ada 2, yaitu

1. Menggunakan Marker, yakni AR ini hanya akan menampilkan objek virtual jika aplikasi AR-nya telah berhasil mendeteksi marker atau penanda yang berupa gambar hitam putih. Contohnya seperti yang ditunjukan pada Gambar 2 berikut ini, yaitu marker hiro. Penggunaan marker ini untuk penanda dalam menampilkan objek baju virtual setelah kamera dalam smartphone berhasil mengenali marker yang digunakan (Hendrawan dkk, 2016).

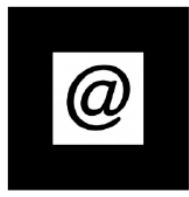

Gambar 2. Marker hitam putih (Hendrawan dkk, 2016)

2. Markeless, yakni AR yang memanfaatkan objek riil (tidak harus gambar hitam putih) sebagai markernya untuk menampilkan objek virtualnya. 
AR tipe ini bertujuan untuk menghasilkan interaksi antara komputer dan calon pembeli agar lebih alami dan intuitif dibandingkan dengan model marker (Wahyuningrum dkk, 2014) salah satu penggunaanya adalah untuk menampilkan baju virtual dengan menggunakan badan sebagai markernya.

Euclidean distance adalah metode yang digunakan untuk mengukur jarak antara 2 titik yang berbeda. Metode ini akan digunakan untuk mengukur lebar punggung calon pembeli dengan memanfaatkan data skeleton yang didapatkan dari hasil kalibrasi. Berikut adalah persamaan Euclidean Distance untuk titik yang mempunyai ruang 3 dimensi (Negoro, 2015):

$$
\mathrm{d}_{\text {skeleton }}=\sqrt{(\mathrm{x} 1-\mathrm{x} 2)^{2}+(y 1-y 2)^{2}+(z 1-z 2)^{2}}
$$

\section{Keterangan :}

$\mathrm{d}_{\text {skeleton }}=$ lebar punggung calon pembeli

$\mathrm{x}_{1}=$ koordinat $\mathrm{x}$ pada titik skeleton_left_shoulder .

$\mathrm{x}_{2}=$ koordinat $\mathrm{x}$ pada titik skeleton_right_shoulder .

$\mathrm{y}_{1}=$ koordinat y pada titik skeleton_left_shoulder.

$\mathrm{y}_{2}=$ koordinat y pada titik skeleton_right_shoulder.

$\mathrm{z}_{1}=$ koordinat $\mathrm{z}$ pada titik skeleton_left_shoulder.

$\mathrm{z}_{2}=$ koordinat $\mathrm{z}$ pada titik skeleton_right_shoulder.

Untuk menguji keakuratan sistem, maka hasil rekomendasi ukuran pakaian dibandingkan dengan ukuran riil badan calon pembeli dengan menggunakan standart ukuran pakaian orang
Indonesia. Tabel 1 adalah acuan dalam standarisasi ukuran pakaian.

Tabel 1. Ukuran Pakaian Dewasa

\begin{tabular}{lcccc}
\hline Ukuran & S & M & L & XL \\
\hline $\begin{array}{l}\text { Lebar punggung } \\
\text { (Pria) }\end{array}$ & $40 \mathrm{~cm}$ & $42 \mathrm{~cm}$ & $44 \mathrm{~cm}$ & $46 \mathrm{~cm}$ \\
$\begin{array}{l}\text { Lebar punggung } \\
\text { (Wanita) }\end{array}$ & $36 \mathrm{~cm}$ & $38 \mathrm{~cm}$ & $40 \mathrm{~cm}$ & $42 \mathrm{~cm}$ \\
\hline
\end{tabular}

(Dewi, 2013)

Untuk menggambarkan alur sistem dari aplikasi ini, digambarkan dalam beberapa flowchart.

Flowchart Rekomendasi Ukuran Pakaian, flowchart ini menggambarkan alur sistem dari fungsi rekomendasi ukuran pakaian. Gambar 5 berikut adalah rekomendasi ukuran pakaian pria dewasa, sedangkan untuk pakaian wanita bentuk flowchartnya hampir sama hanya yang berbeda adalah nilai-nilai ukuran yang mengacu pada Tabel 1. Flowchart memilih model pakaian ditunjukkan pada Gambar 6 berikut ini. Flowchart penambahan pakaian 3D yang ditunjukan dalam Gambar 7 adalah alur sistem untuk menampilkan augmented reality berupa pakaian 3D yang melekat tepat dibadan calon pembeli pada posisi skeleton_neck. Maka marker yang digunakan pada sistem ini adalah badan calon pembeli tersebut.
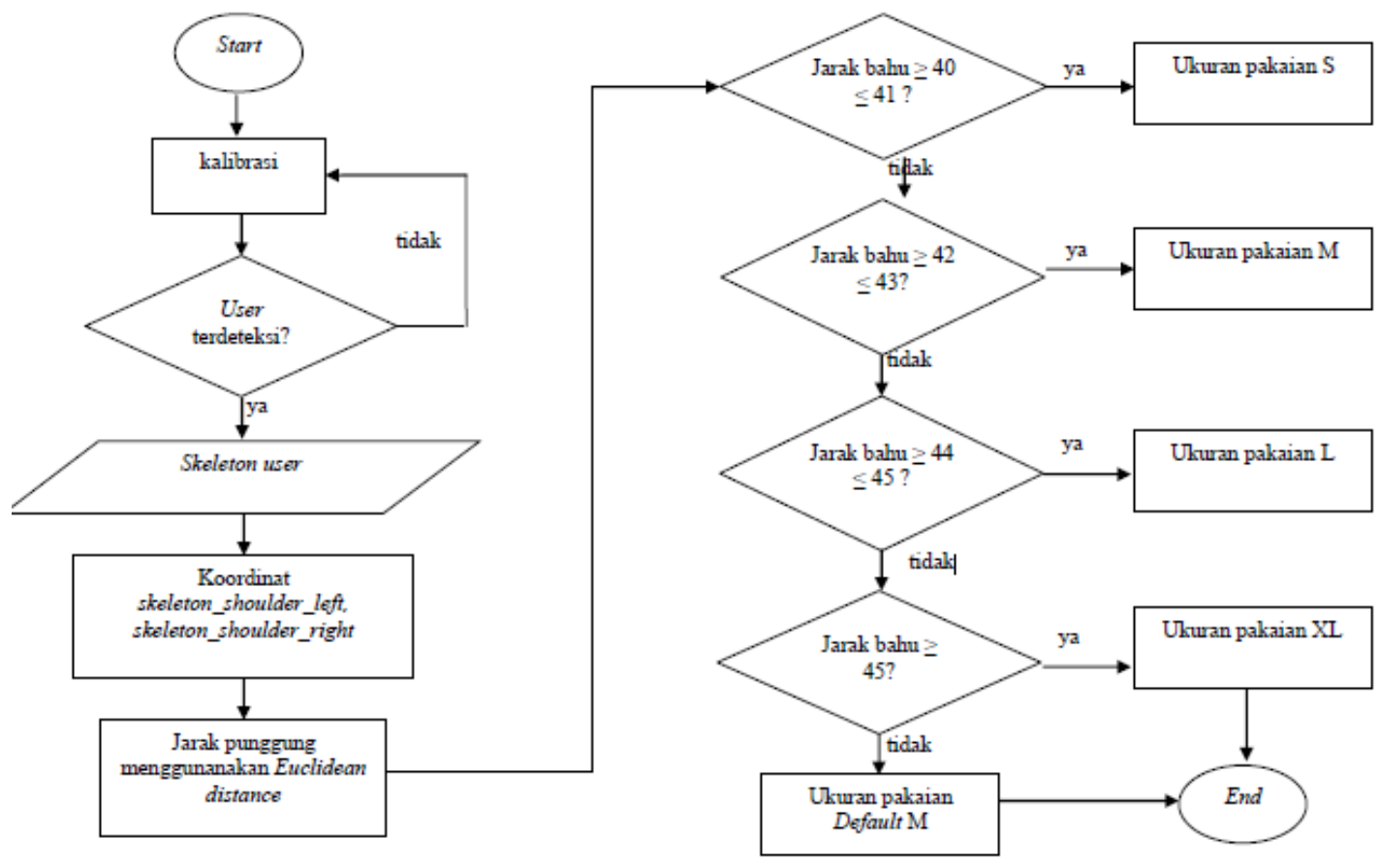

Gambar 5. Flowchart Rekomendasi Ukuran Pakaian Dewasa Pria. 


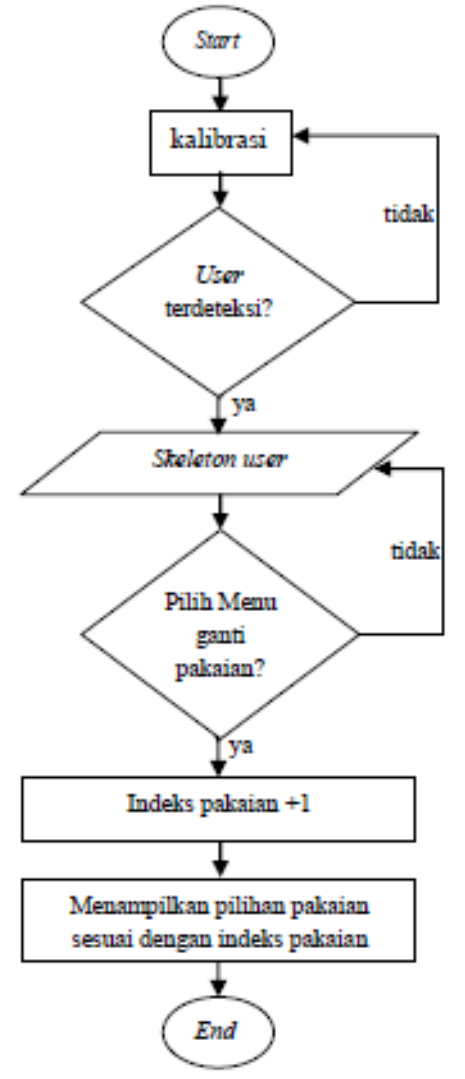

Gambar 6. Flowchart milih model pakaian

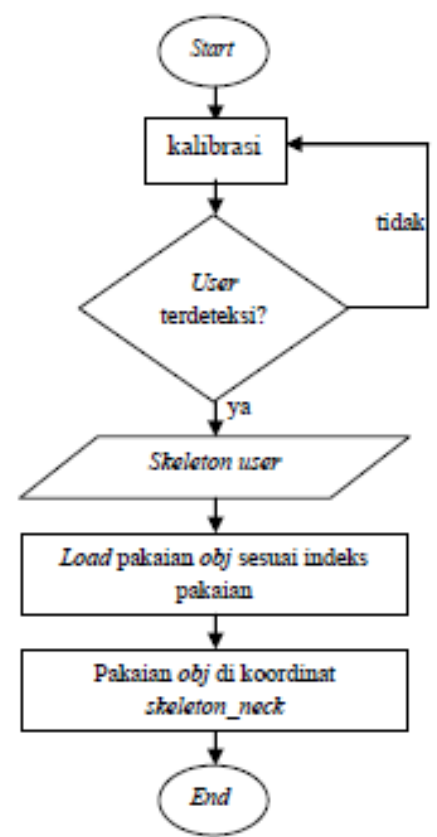

Gambar 7. Flowchart penambahan pakaian 3d

\section{IMPLEMENTASI SISTEM}

Implementasi sistem dalam penelitian ini, dilakukan dalam beberapa tahapan sebagai berikut ini.

\subsection{Proses Kalibrasi}

Saat calon pembeli berdiri di depan Kinect, maka proses kalibrasi berhasil ketika dapat mendeteksi keberadaan seluruh bagian badan calon pembeli. Berikutnya Kinect akan menyimpan data skeleton dari calon pembeli yang akan digunakan dalam sistem rekomendasi ukuran pakaian. Proses kalibrasi ini juga sebagai proses deteksi marker yang berupa badan calon pembeli untuk menambahkan baju virtual ke badannya. Proses ini menggunakan tekhnologi Augmented Reality.

\subsection{Sistem Rekomendasi Pakaian}

Lebar punggung dalam sistem diperoleh dari data skeleton yang telah tersimpan dalam tahap kalibrasi. Data skeleton yang digunakan adalah skeleton_shoulder_left dan skeleton_shoulder_right. Diukur jarak antara dua titik tersebut dengan mengacu pada persamaan (1). Namun, dari hasil tersebut masih ditambah 10 untuk calon pembeli pria dan ditambah 8 untuk calon pembeli wanita. Penambahan ini dilakukan agar ukuran baju tepat berada di badan calon pembeli. Penambahan 10 dan 8 diberikan karena titik skeleton_shoulder_left dan skeleton_shoulder_right dengan titik asli lingkar kerung lengan kiri dan lingkar kerung lengan kanan tidak sama. Sehingga jika tidak ada penambahan 10 dan 8 akan mempunyai hasil yang memiliki perbedaan yang signifikan antara lebar punggung real dengan lebar punggung yang dihasilkan oleh sistem. Nilai 10 dan 8 diperoleh dari selisih jarak antara titik skeleton_shoulder_left dengan titik lingkar kerung lengan kiri dan titik skeleton_shoulder_right dengan titik lingkar kerung lengan kanan. Ilustrasi penambahan angka 8 atau 10 seperti pada Gambar 8 .

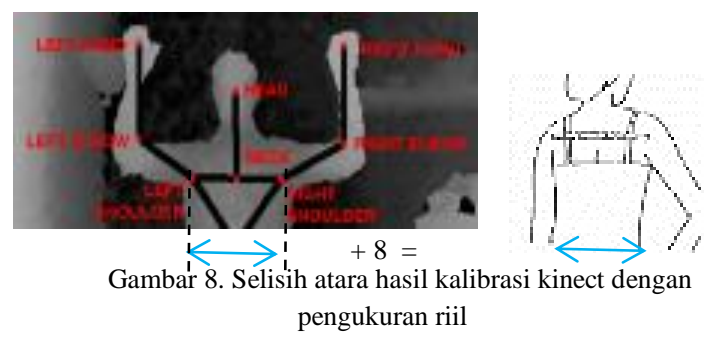

Dari nilai tersebut akan dicocokan dengan Tabel 1 yang disesuaikan dengan jenis kelamin dari calon pembeli. Output dari sistem akan memberikan rekomendasi ukuran pakaian berupa gambar ukuran pakaian antara S,M,L,XL yang melekat pada badan calon pembeli. 


\subsection{Penambahan Pakaian 3D pada badan calon pembeli}

Penambahan pakaian 3D pada calon pembeli dilakukan ketika calon pembeli memilih pakaian yang diinginkan. Virtual pakaian 3D akan ditambahkan pada skeleton_neck dari calon pembeli.

Setelah pakaian diletakkan pada koordinat tersebut, maka akan dilakukan penambahan posisi pakaian 3D terhadap sumbu x sebesar -5 dan terhadap sumbu y sebesar +20. Hal ini dikarenakan titik skeleton_neck yang tidak sesuai dengan peletakan posisi pakaian secara riil. Untuk mendapatkan posisi baju yang ideal maka harus ada proses penambahan tersebut seperti yang diilustrasikan pada Gambar 9 .

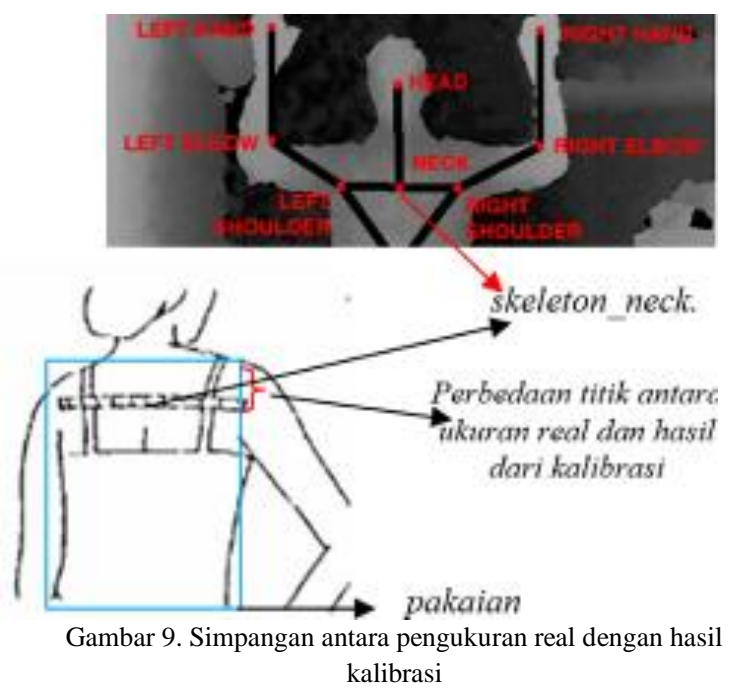

Penambahan pakaian 3D pada badan calon pembeli ini menggunakan teknologi augmented reality dengan teknik markerless, dimana prosesnya adalah sebagai berikut : Sistem telah menyimpan data pakaian 3D dalam format 3D image blender. Ketika sistem mendeteksi calon pembeli telah memilih pakaian yang diinginkan, maka sistem akan melakukan load file pakaian 3D yang sesuai dengan pilihan calon pembeli untuk kemudian ditampilkan pada koordinat skel_neck. Selanjutnya sistem akan melakukan scaling pada pakaian 3D sesuai dengan ukuran pakaian yang akan direkomendasikan. Jadi yang dijadikan sebagai marker adalah badan calon pembeli dari hasil proses kalibrasi dari Kinect.

\subsection{Navigasi sistem Ganti Pakaian 3D}

Mengganti pakaian 3D dapat dilakukan dengan mengolah data skeleton_right_hand sebagai acuan. Data skeleton_righ_hand akan dijadikan pointer. Data skeleton_right_hand sendiri mewakili telapak tangan kanan calon pembeli. Ketika telapak tangan kanan calon pembeli diarahkan pada button mengganti pakaian, dalam delay waktu 3 detik pakaian 3D akan diganti dengan pakian 3D yang lain sesuai urutan pakaian 3D yang disimpan dalam array.

Dalam sistem meliputi tombol navigasi untuk mengganti pilihan baju, tombol select untuk memilih baju, tombol save untuk menyimpan gambar calon pembeli dan tombol exit. Ketika koordinat skeleton_right_hand berada pada koordinat salah satu tombol yang sudah disebutkan diatas maka sistem akan menjalankan sesuai dengan fungsi tombol tersebut.

\section{ANALISIS DAN UJI COBA}

Dalam tahap ini dilakukan analisis dan uji coba untuk mengetahui tingkat akurasi sistem. Variabel uji coba yang digunakan adalah tinggi Kinect (yakni jarak menempatkan Kinect diukur dari ketinggian tanah datar) dan jarak antara calon pembeli dengan sensor Kinect. Tinggi Kinect dibagi menjadi tiga yaitu $55 \mathrm{~cm}, 65 \mathrm{~cm}$, dan $75 \mathrm{~cm}$. Sementara untuk jarak calon pembeli dengan sensor Kinect dibedakan dengan jarak $200 \mathrm{~cm}, 225 \mathrm{~cm}$, dan $250 \mathrm{~cm}$ dari Kinect. Uji coba dilakukan pada 29 calon pembeli yang terdiri dari wanita dan pria.

\subsection{Analisis dan Uji Coba Rekomendasi Ukuran Pakaian}

Dari keseluruhan uji coba, ternyata hasil rekomendasi ukuran pakaian dari sistem yang sesuai dengan ukuran asli badan calon pembeli adalah sebanyak 108 percobaan untuk pakaian wanita dan 153 percobaan untuk pakaian pria. Detil hasil ujicoba dapat dilihat pada Tabel 2 dan Tabel 3.

Sedangkan Tabel 4 adalah hasil rekapitulasi akurasi yang disimpulkan dari 2 tabel sebelumnya. Maka dapat disimpulkan bahwa sistem ini memiliki tingkat akurasi rata-rata sebesar 70\%. Namun percobaan pada ketinggian Kinect $55 \mathrm{~cm}$ dengan berbagai macam variasi jarak antara calon pembeli dengan Kinect sistem ini memiliki tingkat akurasi sebesar rata-rata $89 \%$. 
Tabel 2. Data Uji Coba Rekomendasi Ukuran Baju Sistem pada Calon pembeli Wanita

\begin{tabular}{|c|c|c|c|c|c|c|c|c|c|c|}
\hline \multirow{3}{*}{$\begin{array}{l}\text { Tinggi Kinet } \\
\text { Jarak Kinect } \\
\text { Calon Pembeli }\end{array}$} & \multirow[b]{3}{*}{ Ukuran } & \multicolumn{3}{|c|}{$55 \mathrm{~cm}$} & \multicolumn{3}{|c|}{$65 \mathrm{~cm}$} & \multicolumn{3}{|c|}{$75 \mathrm{~cm}$} \\
\hline & & $200 \mathrm{~cm}$ & $225 \mathrm{~cm}$ & $250 \mathrm{~cm}$ & $200 \mathrm{~cm}$ & $225 \mathrm{~cm}$ & $250 \mathrm{~cm}$ & $200 \mathrm{~cm}$ & $225 \mathrm{~cm}$ & $250 \mathrm{~cm}$ \\
\hline & & \multicolumn{9}{|c|}{ Rekomendasi ukuran baju } \\
\hline Wanita 1 & $\mathrm{~S}$ & $\mathrm{~S}$ & $\mathrm{~S}$ & $\mathrm{~S}$ & $\mathrm{~S}$ & $\mathrm{~S}$ & $\mathrm{~S}$ & $\mathrm{~S}$ & $\mathrm{~S}$ & $\mathrm{~S}$ \\
\hline Wanita 2 & M & M & M & M & M & M & $\mathrm{S}$ & $\mathrm{L}$ & $\mathrm{S}$ & $\mathrm{S}$ \\
\hline Wanita 3 & $\mathrm{~L}$ & $\mathrm{~L}$ & XL & $\mathrm{L}$ & $\mathrm{L}$ & $\mathrm{L}$ & M & $\mathrm{L}$ & M & M \\
\hline Wanita 4 & $\mathrm{X}$ & XL & XL & XL & XL & XL & XL & $\mathrm{S}$ & $\mathrm{L}$ & $S$ \\
\hline Wanita 5 & $\dot{\mathrm{S}}$ & $S$ & S & S & S & S & S & $\mathrm{S}$ & S & S \\
\hline Wanita 6 & $\mathrm{~L}$ & $\mathrm{~L}$ & $\mathrm{~L}$ & M & $\mathrm{L}$ & M & XL & M & XL & M \\
\hline Wanita 7 & $\mathrm{~S}$ & S & S & $S$ & $\mathrm{~S}$ & $\mathrm{~S}$ & $S$ & $\mathrm{~S}$ & $\mathrm{~S}$ & $\mathrm{~S}$ \\
\hline Wanita 8 & $\mathrm{~S}$ & $S$ & S & S & S & M & S & $S$ & $S$ & $S$ \\
\hline Wanita 9 & M & M & M & M & S & M & M & M & $S$ & $\mathrm{~L}$ \\
\hline Wanita 10 & $\mathrm{~S}$ & S & S & S & S & S & $S$ & $\mathrm{~S}$ & S & S \\
\hline Wanita 11 & M & M & $\mathrm{L}$ & M & M & M & M & M & M & $\mathrm{S}$ \\
\hline Wanita 12 & M & M & M & M & $\mathrm{S}$ & M & S & M & $\mathrm{L}$ & M \\
\hline
\end{tabular}

Tabel 3. Data Uji Coba Rekomendasi Ukuran Baju Sistem pada Calon pembeli Pria

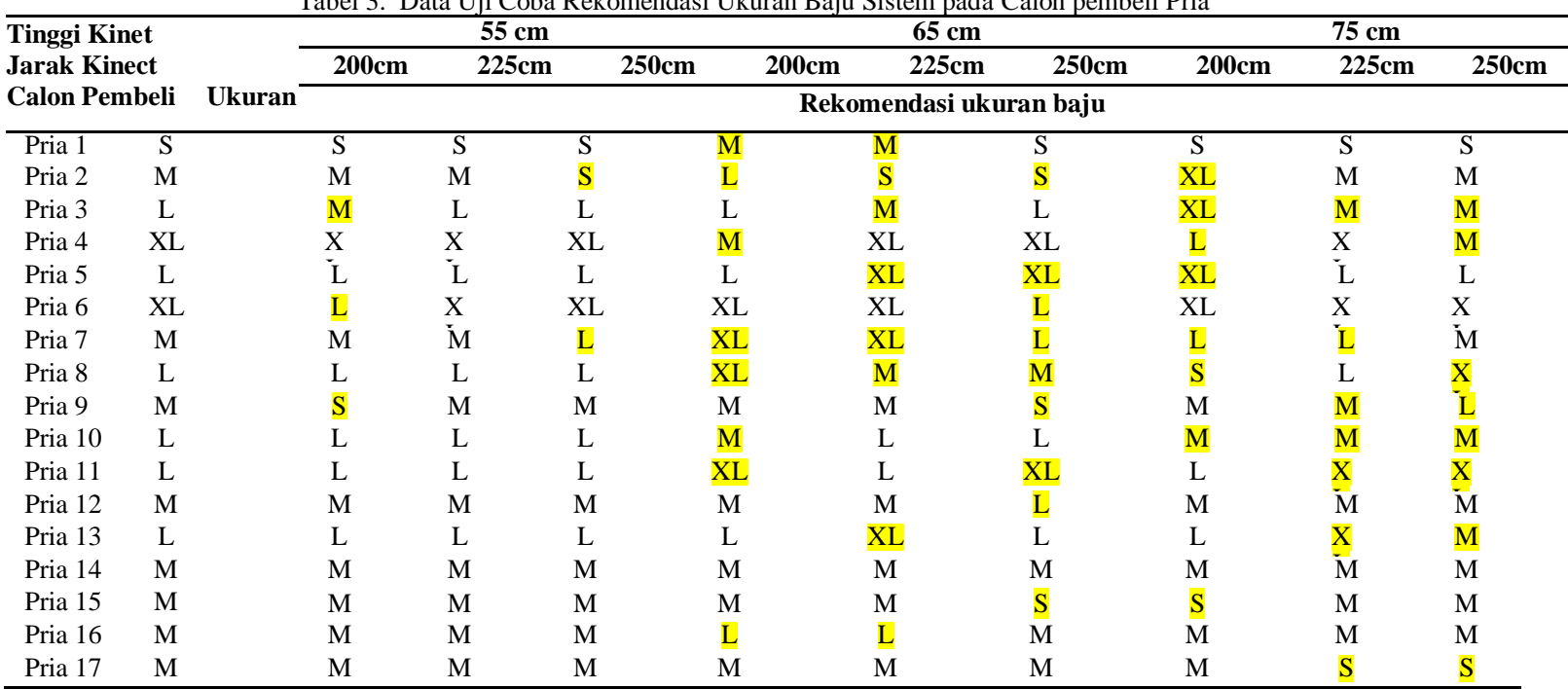

Tabel 4. Tingkat Akurasi Untuk Percobaan Pakaian

\begin{tabular}{|c|c|c|c|c|c|}
\hline \multirow[t]{3}{*}{ Tinggi Kinect } & \multirow[t]{3}{*}{ Jarak Kinect } & \multicolumn{4}{|c|}{ Kesesuaian Ukuran } \\
\hline & & \multicolumn{2}{|c|}{ Pria } & \multicolumn{2}{|c|}{ Wanita } \\
\hline & & Benar & Salah & Benar & Salah \\
\hline \multirow[t]{3}{*}{$55 \mathrm{~cm}$} & $200 \mathrm{~cm}$ & 14 & 3 & 12 & 0 \\
\hline & $225 \mathrm{~cm}$ & 17 & 0 & 10 & 2 \\
\hline & $250 \mathrm{~cm}$ & 15 & 2 & 10 & 2 \\
\hline \multicolumn{2}{|c|}{ Tingkat Akurasi } & \multicolumn{2}{|c|}{0,901960784} & \multicolumn{2}{|c|}{0,888888889} \\
\hline \multirow[t]{3}{*}{$65 \mathrm{~cm}$} & $200 \mathrm{~cm}$ & 9 & 8 & 10 & 2 \\
\hline & $225 \mathrm{~cm}$ & 9 & 8 & 10 & 2 \\
\hline & $250 \mathrm{~cm}$ & 8 & 9 & 8 & 4 \\
\hline \multicolumn{2}{|c|}{ Tingkat Akurasi } & \multicolumn{2}{|c|}{0,509803922} & 0,777 & \\
\hline \multirow[t]{3}{*}{$75 \mathrm{~cm}$} & $200 \mathrm{~cm}$ & 9 & 8 & 10 & 2 \\
\hline & $225 \mathrm{~cm}$ & 10 & 7 & 6 & 6 \\
\hline & $250 \mathrm{~cm}$ & 8 & 9 & 6 & 6 \\
\hline \multicolumn{2}{|c|}{ Tingkat Akurasi } & \multicolumn{2}{|c|}{0,529411765} & 0,6111 & \\
\hline \multicolumn{2}{|c|}{ Rata-rata Tingkat Akurasi } & \multicolumn{2}{|c|}{0,647058824} & 0,7592 & \\
\hline
\end{tabular}

Faktor lain yang mempengaruhi hasil uji coba adalah, pose calon pembeli. Ketika calon pembeli merentangkan tangan maka akan diasumsikan memiliki lebar punggung yang lebih lebar dibandingkan calon pembeli dengan pose tegak lurus oleh sistem. Selain itu ketinggian peletakan Kinect juga mempengaruhi hasil lebar punggung yang didetekesi oleh sistem. Jika tinggi peletakan Kinect semakin tinggi maka calon pembeli akan terlihat juga semakin besar, karena akan mengasumsikan lebar punggung calon pembeli yang semakin lebar seperti yang terlihat pada beberapa percobaan di Tabel 2 dan Tabel 3.

Faktor terakhir yang mempengaruhi hasil dari lebar punggung sistem adalah ukuran tebal tidaknya baju yang dikenakan oleh calon pembeli. Semakin tebal atau besar baju yang dikenakan calon pembeli maka sistem akan mendeteksi lebar punggung calon pembeli lebih besar dibandingkan dengan lebar punggung riil calon pembeli. 


\subsection{Analisis dan Uji Coba Pelekatan Pakaian 3D}

Uji coba ini dilakukan untuk mengetahui posisi pakaian 3d yang ditambahkan pada badan calon pembeli. Hasil dari uji coba ini dapat dilihat pada Gambar 10.

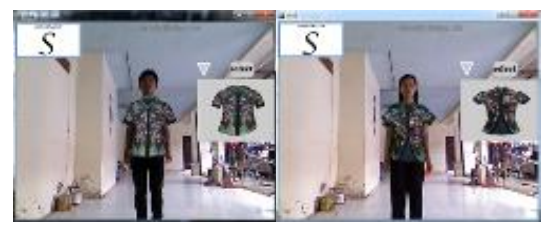

Gambar 10. Uji coba penambahan pakaian

Dari hasil uji coba tersebut, pelekatan pakaian pada badan calon pembeli sudah sesuai dengan yang sebenarnya. Hal ini dikarenakan peletakan posisi pakaian virtual yang telah ditambahkan pada calon pembeli sesuai dengan koordinat data skeleton_neck yang didapat dari Kinect.

\subsection{Analisis dan Uji Coba Ganti Pakaian}

Uji coba ini dilakukan untuk mengetahui keakuratan koordinat skeleteon_right_hand. Hasil dari uji coba ini dapat dilihat pada Gambar 11.

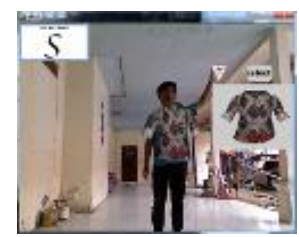

Gambar 11. Pakaian 3D setelah diganti.

Posisi koordinat Skeleton_right_hand yang didapat dari Kinect dapat mewakili telapak tangan kanan untuk dijadikan pointer untuk mengoperasikan tombol mengganti pakaian virtual.

\subsection{Analisis dan Uji Coba Rotasi Pakaian}

Analisis dan uji coba ini dilakukan untuk mengadaptasi pakaian 3D terhadap gerakan memutar yang dilakukan oleh calon pembeli. Hal ini biasanya digunakan oleh calon pembeli untuk melihat apakah pakaian yang dicoba memang cocok untuk dirinya.

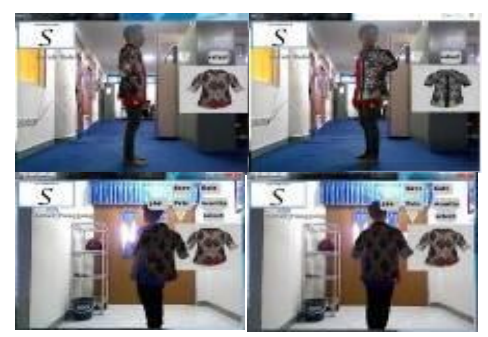

Gambar 12. berotasi ke Kanan $90^{\circ}$, ke kiri $90^{\circ}$, Balik Kanan $180^{\circ}$ dan Balik Kiri $180^{\circ}$
Dimulai dari gambar paling atas searah jarum jam Gambar 12 berikut adalah hasil uji coba ketika calon pembeli berotasi ke Kanan $90^{\circ}$, ke kiri $90^{\circ}$, Balik Kanan $180^{\circ}$ dan Balik Kiri $180^{\circ}$. Terlihat dalam gambar tersebut bahwa, kemanapun calon pembeli memutar badannya, pakaian virtual tersebut tetap melekat di badannya.

\subsection{Analisis dan Uji Coba Scale Pakaian}

Analisis dan uji coba ini dilakukan untuk mengetahui melihat bagaimana pakaian virtual ini berpengaruh terhadap jarak. Secara umum, gambar akan tampak mengecil jika jauh dari pandangan/cermin. Uji coba ini akan melihat bagaimana penampilan pakaian virtual ketika calon pembeli pada jarak $200 \mathrm{~cm}, 225 \mathrm{~cm}$ dan $250 \mathrm{~cm}$. Hasil dari uji coba ini dapat dilihat pada Gambar 13, dimana ketika calon pembeli berada semakin jauh jaraknya dengan Kinect maka pakaian virtual 3Dnya juga semakin mengecil.

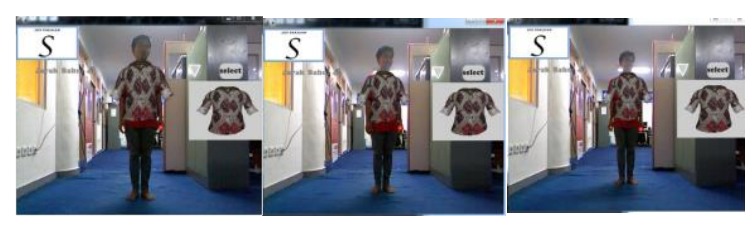

Gambar 13. Jarak calon pembeli Dengan Kinect 200 Cm, 225 Cm, dan $250 \mathrm{~cm}$

$\begin{array}{ccc}\text { Hal ini menggunakan konsep skala } \\ \text { pengecilan/pembesaran gambar } & \text { yang }\end{array}$ diimplementasikan pada pakaian virtual 3D. Namun untuk perhitungan rekomendasi ukuran tetap menggunakan persamaan 1 . Untuk detil hasil uji coba dengan variasi jarak dapat dilihat pada Tabel 2 dan Tabel 3 .

\section{KESIMPULAN}

Aplikasi ruang ganti virtual ini ini mampu memberikan rekomendasi ukuran pakaian kepada calon pembeli dengan tingkat akurasi sebesar $70 \%$ dengan memperhatikan ketinggian peletakan Kinect serta jarak antara calon pembeli dan Kinect. Sistem akan optimal dalam memberikan rekomendasi sebesar 90,8 \% jika peletakan Kinect setinggi 55 m. Sistem ini juga dilengkapi dengan fitur berganti pakaian. Selayaknya orang mencoba, sistem ini juga mengadopsi keinginan calon pembeli ketika mencoba pakaian, maka dia akan bergerak ke kanan, kiri atau bahkan membalik badan serta mendekat atau menjauh ke cermin. Hasil dari uji coba, memperlihatkan bahwa pakaian virtual masih tetap melekat pada badan calon pembeli walaupun dia telah 
melakukan pergerakan ke kanan, kiri, ataupun membalik badan. Dan pakaian virtual juga menunjukkan semakin membesar/mengecil jika calon pembeli mendekat/menjauh dari Kinect.

\section{DAFTAR PUSTAKA}

AZUMA R.T. 1997. A survey of augmented reality. Teleoperators and Virtual Environments, $6(4)$.

BECK, M. 2015. The power of Virtual Fitting Rooms on specific curiosity, online patronage intention and online purchase intention. International Congress of Marketing Trends, Paris.

DEWI, I. A. 2013. Analisis dan Desain Body Measurement pada Virtual Dressing Room. Konferensi Nasional Sistem dan Informatika, 9 Nopember, Bali

HENDRAWAN, Y. F., WAHYUNINGRUM, R.T., SIRADJUDDIN, I. A., KURNIAWATI, A. \& KUSUMANINGSIH, A. 2016. Virtual Fitting Room Android based Mobile Application using Augmented Reality for the Madura Batik Clothes. Advanced Science Letters, 22 (7) 1783-1786.

HENGEVELT, J. 2014. Dressing Rooms: Love It Or Leave It!, Master thesis, Master Communication Studies Marketing Communication University of Twente.

HRUSKA, J. 2016. Can we finally admit that Kinect is dead?.

https://www.extremetech.com/gaming/2302 52-can-we-finally-admit-that-Kinect-isdead

LIAW, G.F. \& CHEN, C.H. 2013. The Impact of Virtual Fitting Room Technology on Consumers, Management and Administrative Sciences Review, 2(1), 2335 .

MISRA, S. \& ARIVAZHAGAN, D. . 2015. Implementation Of Virtual Fitting Room For Online Fabric Buyers. AMET International Journal of Physical \& Chemical Sciences, ACJPS, 1(1), 13-22.

NEGORO, M. T. 2015, Rancangan Bangun Aplikasi Ruang Ganti Virtual Berdasarkan Skeleton Tracking dan Depth Data Menggunakan Microsoft Kinect. Tugas Akhir, Teknik Informatika Institut Teknologi Sepuluh November Surabaya.

RIAZ, A. \& RAMAN, S. 2015. The Emerging Trend of Online Shopping: A Literature Review, International Journal of Accounting, Business and Management, 1(1), 1-8.
SIGIT, W.,SETIAWARDHANA \& HENRITA, P. 2014. Sistem Pengepasan Pakaian Berbasis Pustaka XNA Menggunakan Kamera Kinect. Jurnal Link, 21(2), 33-39

WAHYUNINGRUM, R.T., SIRADJUDDIN, I. A., HENDRAWAN, Y. F., KURNIAWATI, A. \& KUSUMANINGSIH, A. 2014. Double Difference Motion Detection and Its Application for Madura Batik Virtual Fitting Room. Telkomnika (Telecommunication Computing Electronics and Control), 12(1), 115-122

WEBB, J. \& ASHLEY, J. 2012. Beginning Kinect Programming With The Microsoft Kinect SDK $1^{\text {st }}$ edition., Apress 
Halaman ini sengaja dikosongkan 